University of Nebraska - Lincoln

DigitalCommons@University of Nebraska - Lincoln

\title{
DNA Content and Ploidy Determination of Bromegrass Germplasm Accessions by Flow Cytometry
}

\author{
Metin Tuna \\ University of Trakya \\ Kenneth P. Vogel \\ University of Nebraska-Lincoln, kvogel1@unl.edu \\ K. Arumugantathan \\ University of Nebraska-Lincoln \\ Kulvinder S. Gill \\ University of Nebraska-Lincoln
}

Follow this and additional works at: https://digitalcommons.unl.edu/usdaarsfacpub

Tuna, Metin; Vogel, Kenneth P.; Arumugantathan, K.; and Gill, Kulvinder S., "DNA Content and Ploidy Determination of Bromegrass Germplasm Accessions by Flow Cytometry" (2001). Publications from USDA-ARS / UNL Faculty. 1910.

https://digitalcommons.unl.edu/usdaarsfacpub/1910

This Article is brought to you for free and open access by the U.S. Department of Agriculture: Agricultural Research Service, Lincoln, Nebraska at DigitalCommons@University of Nebraska - Lincoln. It has been accepted for inclusion in Publications from USDA-ARS / UNL Faculty by an authorized administrator of DigitalCommons@University of Nebraska - Lincoln. 


\title{
DNA Content and Ploidy Determination of Bromegrass Germplasm Accessions by Flow Cytometry
}

\author{
Metin Tuna, Kenneth P. Vogel,* K. Arumuganathan, and Kulvinder S. Gill
}

\begin{abstract}
Species of the genus Bromus represent ploidy states from diploid to decaploid. Ploidy determination of Bromus germplasm is necessary before it can be effectively used in breeding or genetic studies. The objective of this study was to characterize the ploidy of 322 accessions of four Bromus species [Bromus inermis Leyss, B. riparius Rehm, $B$. biebersteinii Roem and Schult., and $B$. inermis ssp. pumpellianus (Scribn) Wagnon] that are in the USDA National Plant Germplasm System (NPGS). Flow cytometry was used to determine DNA content of 10 plants of each accession. Mean DNA contents were correlated to ploidy level with root tip chromosome counts on selected accessions whose DNA content indicated that they represented different ploidy levels. On the basis of DNA content ( $\mathrm{pg} 2 \mathrm{C}^{-1}=$ DNA content of a diploid somatic nucleus) and chromosome counts, mean DNA content

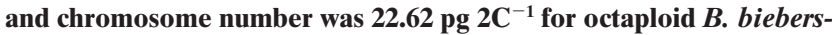
teinii $(2 n=8 x=56), 26.07 \mathrm{pg}^{2} \mathrm{C}^{-1}$ for decaploid $B$. biebersteinii

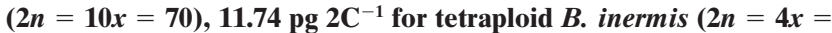

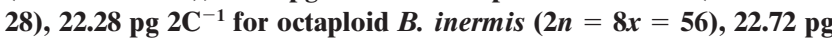
$2 \mathrm{C}^{-1}$ for octaploid $B$. inermis ssp. pumpellianus $(2 n=8 \mathrm{x}=56), 26.5$ pg $2 \mathrm{C}^{-1}$ for decaploid $B$. inermis ssp. pumpellianus $(2 n=10 x=70)$,

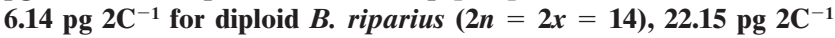

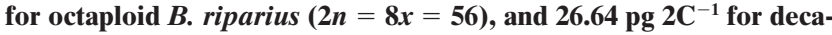
ploid $B$. riparius $(2 n=10 x=70)$. Standard deviations of the mean values were $0.88 \mathrm{pg}^{-1} \mathrm{C}^{-1}$ or less. Most $B$. inermis and $B$. inermis ssp. pumpellianus accessions were octaploid $(93.75 \%)$, while the majority of the $B$. riparius and $B$. biebersteinii were decaploid $(92.30 \%)$. The $B$. inermis and related species in the USDA NPGS were collected primarily from areas in the former USSR. The NPGS bromegrass germplasm could be enhanced by collections from western and central Europe, the Middle East, and China.
\end{abstract}

$\mathrm{T}$ HE GENUS Bromus L. contains more than 100 species distributed over all continents (Gould and Shaw, 1983). Smooth bromegrass (B. inermis Leyss.) and meadow bromegrass (B. riparius Rehm.) are the two most widely used species of the Bromus genus in North America. The species name B. biebersteinii Roem. and Schultz has been incorrectly applied to meadow bromegrasses in North America until recently (Vogel et al., 1996). Smooth bromegrass and pumpelly brome $[B$. inermis spp. pumpellianus (Scribn.) Wagnon.] are closely related since they are completely interfertile and have regular chromosome pairing at meiosis (Armstrong,

Metin Tuna, Dep. of Agronomy, Tekirdag Agriculture Faculty, Univ. of Trakya, Tekirdag, Turkey; K.P. Vogel, USDA-ARS, Wheat, Sorghum, and Forage Res. Unit, 344 Keim Hall, Univ. of Nebraska, P.O. Box 830937, Lincoln, NE 68507-0937; K. Arumuganathan, Center for Biotechnology, Univ. of Nebraska, Lincoln, NE 68588; K.S. Gill, Dep. of Agronomy, Univ. of Nebraska, Lincoln, NE 68583-0915; Contribution from Nebraska Agric. Res. Div., Journal Series No. 13155. Reported research is from a dissertation submitted by the senior author (Metin Tuna) in partial fulfillment of the requirements for the Ph.D. degree at the Univ. of Nebraska. Received 17 Oct. 2000. *Corresponding author (kpv@unlserve.unl.edu).

Published in Crop Sci. 41:1629-1634 (2001).
1987). The chloroplast restriction patterns for smooth bromegrass, meadow bromegrass, and pumpelly bromegrass are identical (Pilay and Hilu, 1990).

A ploidy series exists within these species which have the base chromosome number of $n=7$. Reported chromosome numbers for smooth bromegrass are $2 n=28$, 42, and 56 and for meadow bromegrass are 14, 56, and 70 (Tsvelev, 1984; Hill and Myers, 1948; Carnahan and Hill, 1960; Armstrong, 1987; Vogel et al., 1996). The commonly grown form of smooth bromegrass is an autoallooctaploid with a chromosome number of $2 n=$ $8 x=56$, while the tetraploid $(2 n=4 x=28)$ is an allotetraploid (Armstrong, 1973; Elliot and Wilsie, 1948; Hill and Meyers, 1948; Carnahan and Hill, 1960; Vogel et al., 1996). Cultivated meadow bromegrass is decaploid with a chromosome number of $2 n=10 x=70$ (Knowles et al., 1993). Meadow bromegrass $(2 n=70)$ probably contains the same basic genomes as smooth bromegrass $(2 n=56)$ plus a third additional genome (Schultz-Schaeffer, 1960).

Ploidy determinations have traditionally been done by counting chromosomes of stained root tips, but this method is laborious and often difficult with species which have small chromosomes and high ploidy levels and can lead to misclassified germplasm (Brummer et al., 1999). All chromosomes are located in the cell nucleus of plants enabling nuclear DNA content to be used as an estimate of ploidy level. Nuclear DNA content in plants was previously determined by feulgen microspectrophotometry of root tip or shoot tip mitotic cells (Bennett and Smith, 1976). In recent years, flow cytometry has become the preferred technique for estimating the nuclear DNA content because of its ease, quickness, and accuracy (Rayburn et al., 1989; Heslop-Harrison, 1995).

Arumuganathan and Earle (1991a) determined nuclear DNA contents of more than 100 major crop plant species using flow cytometry. Vogel et al. (1999) used flow cytometry to determine the base DNA content of the genomes in the perennial Triticeae. Flow cytometry also has been used to determine the ploidy level of switchgrass (Panicum virgatum L.) (Hultquist et al., 1997; Lu et al., 1998), alfalfa (Medicago sativa L.) (Brummer et al., 1999); and 13 turfgrass species (Arumuganathan et al., 1999). The amount of DNA in plant cells is expressed in picograms (pg) as a "C" value. (Bennett and Smith, 1976). The letter C stands for a "constant" or the amount of DNA in a haploid nucleus or genome; $2 \mathrm{C}$ values represent the DNA content of a diploid somatic nucleus. DNA amounts in picograms

Abbreviations: NPGS, National Plant Germplasm System; pg 2C ${ }^{-1}$, DNA content of a diploid somatic nucleus in picograms; C-value is the DNA amount in the unreplicated haploid nucleus of an organism and stands for "constant." 
can be converted to megabase pairs ( $\mathrm{Mbp}$ ) by means of the conversion factor of $1 \mathrm{pg}=980 \mathrm{Mbp}$ (Bennett et al., 2000). Bennett and Smith (1976) reported DNA content values for octaploid $B$. inermis and $B$. erectus Huds. of $23.6 \mathrm{pg}$ and $23.3 \mathrm{pg} 2 \mathrm{C}^{-1}$, respectively, which were obtained with Feulgen microdensitormetry.

The USDA Plant Germplasm System contains over 255 accessions of $B$. inermis, 49 accessions of $B$. riparius, nine accessions of $B$. inermis ssp. pumpellianus, and nine accessions of $B$. biebersteinii. The ploidy level of most of these accessions was unknown prior to the completion of this research. Lack of information on ploidy levels limits the utility of germplasm forage breeding programs. Hybridization of plants with different ploidy levels can result in nonviable progeny or genetically unstable progeny (Vogel and Pedersen, 1993).

The objectives of this study were to determine the nuclear DNA content of more than 322 bromegrass accessions in the USDA National Plant Germplasm System that are classified as $B$. inermis, $B$. inermis ssp. pumpellianus, $B$. riparius, and $B$. biebersteinii, correlate DNA content with ploidy level for these species, and classify the accessions for ploidy on the basis of DNA content. The ploidy level information was then used to characterize the genomic structure of the smooth, meadow, and pumpelly bromegrass collections.

\section{MATERIALS AND METHODS}

Accessions of $B$. inermis, B. riparius, B. biebersteinii, and $B$. inermis ssp. pumpellianus were obtained from the USDA Regional Plant Introduction Station, Pullman, WA, in December 1995 . Twenty seedlings of each of 322 accessions (255 B. inermis, 49 B. riparius, nine $B$. biebersteinii, and nine $B$. inermis ssp. pumpellianus ) were grown in individual plastic conetainers (22 cm deep, $4 \mathrm{~cm}$ in diameter) which contained a mixture of 2:1:1 soil/peat/vermiculite in the USDA Forage Research
Lab greenhouse at Lincoln, NE. Plants were maintained in the vegetative condition by repeated clippings.

The procedures described by Arumuganathan and Earle (1991b) were used to determine DNA content per nucleus. Briefly, the procedure consists of preparing suspensions of intact nuclei by chopping plant tissues and lysing protoplasts in a $\mathrm{MgSO}_{4}$ buffer mixed with DNA standards and staining the nuclei with propidium iodide (PI) in a solution containing DNase-free RNase. Fluorescence intensities of the stained nuclei were measured by flow cytometry. Values for nuclear DNA content were estimated by comparing fluorescence intensities of the nuclei of the test population with those of a diploid barley (Hordeum vulgare L. cv. Hitchcock) or hexaploid wheat (Triticum aestivum L. cv. Arapahoe) internal DNA standard that was included with the tissue being tested.

Approximately $50 \mathrm{mg}$ of fresh, green tissue from a collared leaf of a Bromus seedling was excised and placed on ice in a sterile $35-$ by $10-\mathrm{mm}$ plastic petri dish. About $20 \mathrm{mg}$ of leaf tissue from seedling barley or wheat leaves were added as a standard. 2C complements of DNA per nucleus for the barley and wheat are 10.68 and $34.68 \mathrm{pg}$, respectively. Barley $(2 n=$ $2 x=14)$ and wheat $(2 n=6 x=42)$ were used as standards because of the large range in DNA content of the strains analyzed. The leaf tissue (bromegrass and standard) was chopped into $0.25-1.0 \mathrm{~mm}$ segments in $1 \mathrm{~mL}$ of solution $\mathrm{A}$ [24 mL MgSO 4 buffer (ice-cold); $25 \mathrm{mg}$ dithiothreitol; $500 \mu \mathrm{L}$ propidium iodide stock $(5.0 \mathrm{mg}$ propidium iodide in $1.0 \mathrm{~mL}$ double distilled $\mathrm{H}_{2} \mathrm{O}$ ); $625 \mu \mathrm{L}$ Triton X-100 stock (1.0 g Tri-

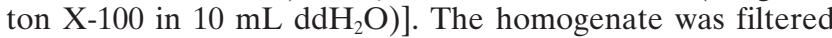
through a $33-\mu \mathrm{m}$ nylon mesh into a microcentrifuge tube and centrifuged (VS-15 microcentrifuge, Shelton Scientific, Shelton, CT) at 13000 RPM for $20 \mathrm{~s}$. The supernatant was discarded, the pellet was resuspended in $400 \mu \mathrm{L}$ of solution B [7.5 mL solution A; $17.5 \mu \mathrm{L}$ RNase (DNase free)] and it was incubated for $15 \mathrm{~min}$ at $37^{\circ} \mathrm{C}$ before flow cytometric analysis.

The prepared material was analyzed in the University of Nebraska Flow Cytometry Core Research Facilities on a standard FACScan model flow cytometer (Becton Dickinson Immunocytometry system, San Jose, CA). For measurement, PI fluorescence area signals (FL2-A) from 1000 nuclei were

Table 1. Nuclear DNA content of Bromus accessions with known chromosome numbers and ploidy level of accessions determined by nuclear DNA content.

\begin{tabular}{|c|c|c|c|c|c|c|c|c|}
\hline \multicolumn{4}{|c|}{ Accessions with known chromosome numbers } & \multicolumn{4}{|c|}{ Accessions with ploidy level determined by DNA content } & \multirow{3}{*}{$\begin{array}{l}\text { Cytogenetic analysis } \\
\text { PI (s)§ or comments }\end{array}$} \\
\hline \multirow{2}{*}{$\begin{array}{l}\text { Number of } \\
\text { accessions }\end{array}$} & \multirow{2}{*}{$\begin{array}{l}\text { Chromosome } \\
\text { number (2n) }\end{array}$} & \multirow{2}{*}{$\begin{array}{c}\text { DNA pg/2C } \\
\text { Mean }\end{array}$} & \multirow[b]{2}{*}{ SD } & \multirow{2}{*}{$\begin{array}{c}\text { Accession } \\
\text { number }\end{array}$} & \multirow[b]{2}{*}{ Ploidy level } & \multirow{2}{*}{$\underset{\text { Mean } \dagger}{\text { DNA }}$} & \multirow{2}{*}{$\underset{\text { SD }}{\text { DNA pg/2C }}$} & \\
\hline & & & & & & & & \\
\hline \multicolumn{9}{|c|}{ Bromus biebersteinii } \\
\hline $1 \S$ & 56 & 22.62 & 0.70 & 1 & $8 x$ & 22.62 & 0.70 & PI 325226 \\
\hline $2 \S$ & 70 & 27.13 & 1.01 & 7 & $10 x$ & 26.07 & 0.79 & PI 172394, PI 341222 \\
\hline \multicolumn{9}{|c|}{ Bromus inermis spp. inermis } \\
\hline $6 \div \S$ & 28 & 11.73 & 0.10 & 14 & $4 x$ & 11.74 & 0.16 & $\begin{array}{l}\text { PI 315385, PI 440201, PI 440202, PI } \\
\text { 440203, PI 440204, PI 499401 }\end{array}$ \\
\hline $19 \$ \S$ & 56 & 22.11 & 0.19 & 233 & $8 x$ & 22.28 & 0.42 & $\begin{array}{l}\text { PI 251861, PI 574512, PI 574514, PI } \\
578551\end{array}$ \\
\hline \multicolumn{9}{|c|}{ Bromus inermis spp. pumpellianus } \\
\hline$\overline{2 \S}$ & 56 & 23.09 & 0.03 & $\begin{array}{l}7 \\
2\end{array}$ & $\begin{array}{l}8 x \\
10 x\end{array}$ & $\begin{array}{l}22.72 \\
26.5\end{array}$ & $\begin{array}{l}0.88 \\
0.14\end{array}$ & PI 372671, PI 562648 \\
\hline \multicolumn{9}{|c|}{ Bromus riparius } \\
\hline $1 \div \S$ & 14 & 6.14 & 0.09 & 1 & $2 x$ & 6.14 & 0.09 & PI 440215 \\
\hline $1 \S$ & 56 & 22.76 & 0.42 & 2 & $8 x$ & 22.15 & 0.86 & PI 315380 \\
\hline $11 \% \S$ & 70 & 26.53 & 0.43 & $\begin{array}{r}41 \\
5\end{array}$ & $\begin{array}{l}\text { 10x } \\
\text { mixed }\end{array}$ & 26.64 & $\begin{array}{l}0.52 \\
1.31\end{array}$ & $\begin{array}{l}\text { PI 440214, PI 536012, PI } 536013 \\
\text { Octa-, deca-, \& aneuploid DNA content }\end{array}$ \\
\hline
\end{tabular}

$\dagger$ Based on all accessions within species and ploidy level for which accession nuclear DNA content standard deviation (SD) for the 10 plants analyzed per accession was less than $1.0 \mathrm{pg}$.

+ Chromosome numbers include data on accessions from Armstrong (1987)

$\S$ Chromosome numbers determined or verified in this study on indicated PI accessions listed in the Cytogenetic analysis column. 
collected by CellQuest software (Becton Dickinson Immunocytometry system, San Jose, CA). A live gate instrument configuration was used by employing the FL2-2 and FSC parameters which allowed the fluorescence measurement from nuclei to be used to generate a histogram of FL2-A. Mean position of G0/G1 (nuclei) peak of sample and internal standard were determined by analyzing the data by CellQuest software. The mean DNA content per plant was based on the 1000 scanned nuclei. The formula used for converting florescence values to DNA content was: Nuclear DNA content $=($ mean position of unknown peak $) /($ mean position of known $) \times$ DNA content of known standard.

Ten seedlings were analyzed for DNA content per accession. One seedling per accession was analyzed twice (subsample a and b) to obtain an estimate of laboratory precision which was $0.03 \mathrm{pg}$ for this study. Plants were reanalyzed for nuclear DNA content if the subsample standard deviation for an accession was greater than $1.0 \mathrm{pg}$, if variation in DNA content among plants indicated that there were differences among plants for ploidy level in that accession, or if a plant had a DNA content that was intermediate between the expected ploidy levels for that species.

After DNA levels were determined, one to six representative accessions (Table 1) with different DNA levels were selected for each species and used for chromosome counting. Cytological investigations were done on root tips. For this purpose, the terminal $1 \mathrm{~cm}$ of the end of fresh roots was excised from plants growing in pots and placed in a vial con-
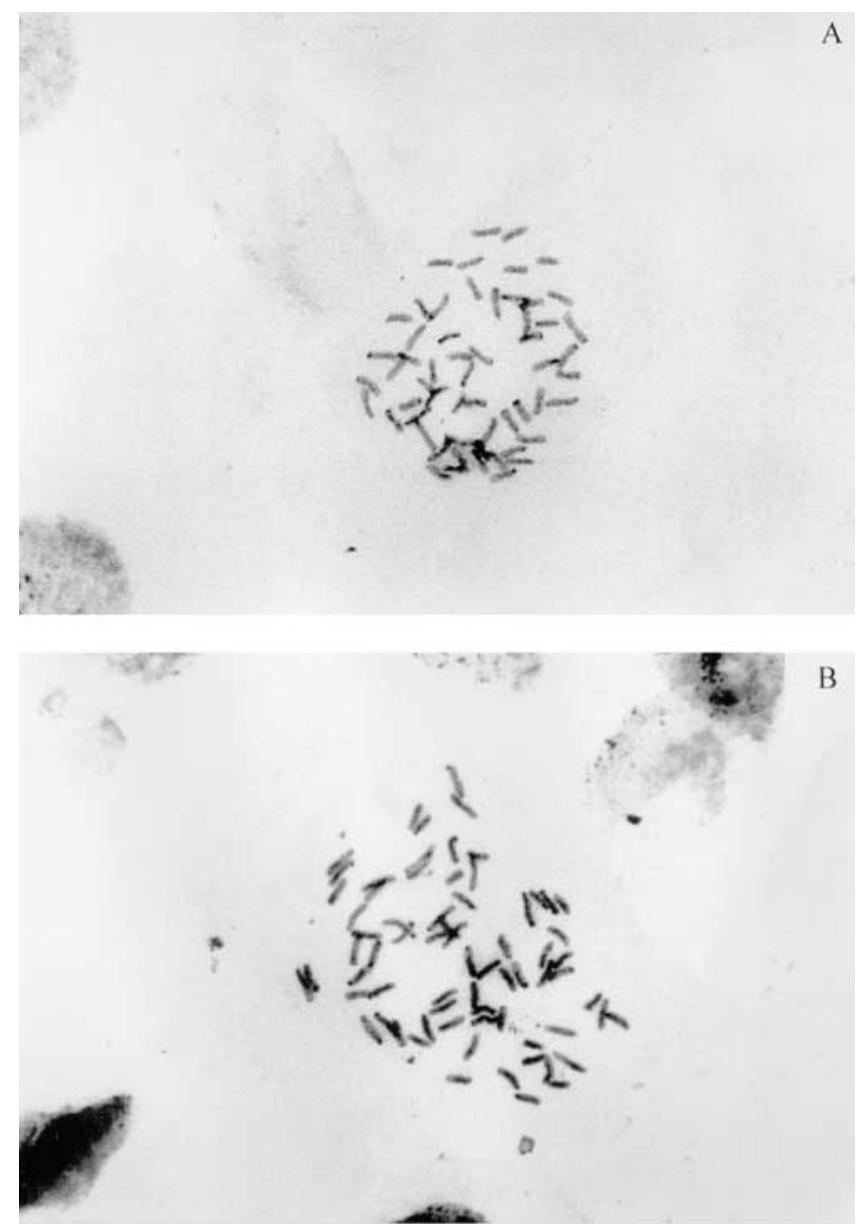

Fig. 1. Bromus biebersteinii chromosomes from root-tip preparations. (A) Octaploid (2n = 56; PI 325226); (B) Decaploid ( $2 n=$ 70; PI 341222) taining $0.05 \%$ colchicine. Colchicine was replaced with ethanol:glacial acetic acid (3:1, v/v) after $3 \mathrm{~h}$. For mitotic analysis, root tips were stained with $1 \%$ acetocarmine for 1 to $3 \mathrm{~h}$ and squashed in a drop of acetic acid. Cells were observed under a light microscope to determine the chromosome number. Approximately 10 cells at metaphase I from a minimum of three plants from each accession selected for chromosome number analyses were observed to determine the chromosome number. We were not able to count chromosome numbers of the decaploid $B$. inermis ssp. pumpellianus accessions since root tips with dividing cells were not found.

\section{RESULTS AND DISCUSSION}

Accurate determination of the chromosome number is difficult in bromegrasses because of their small chromosome size and high number of chromosomes (Hill and Myers, 1948; Barnett, 1955). Colchicine treatment of the root tips resulted in straighter and smaller chromosomes than the cold water treatment and gave better chromosome spreads which allowed us to make more accurate chromosome counts (Fig. 1, 2, 3, 4). All diploid plants had 14 chromosomes and no aneuploids were observed in the diploid accession. Only two aneuploid plants were observed among all tetraploid accessions

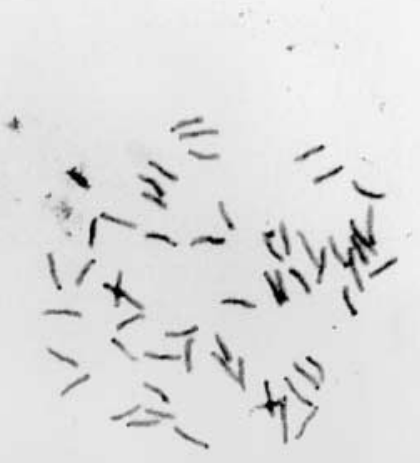

B

Fig. 2. Bromus inermis chromosomes from root-tip preparations. (A) Tetraploid ( $2 n=28$; PI 315385); (B) Octaploid ( $2 n=56$; Lincoln bromegrass). 


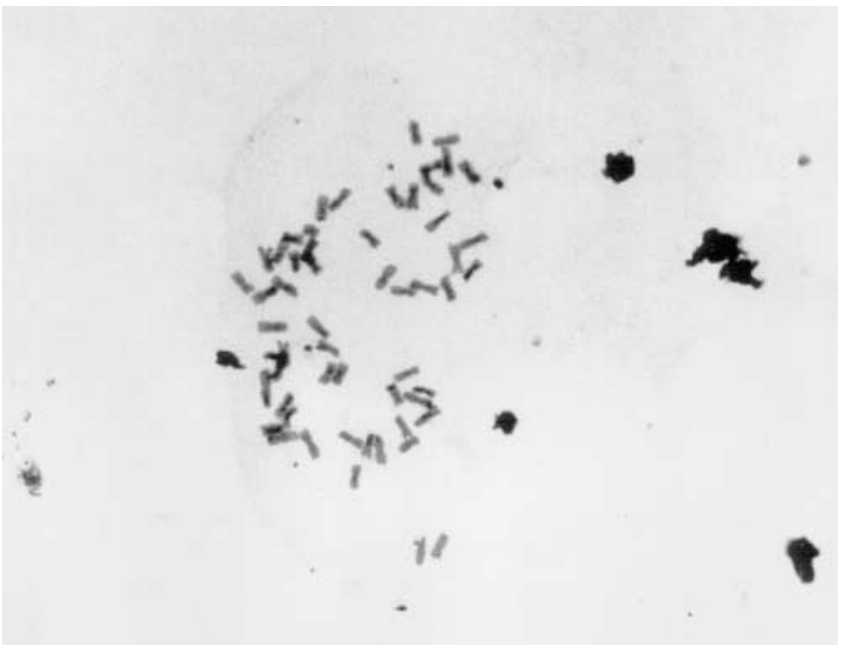

Fig. 3. Octaploid $B$. inermis ssp. pumpellianus chromosomes $(2 n=$ 56; PI 562648) from root-tip preparations.

that were studied cytologically. PI 315385 had a plant with 27 chromosomes and PI 440203 had a plant with 29 chromosomes. More potential aneuploid plants as determined by DNA content (see below) were detected in species with higher ploidy levels but accurate chromosome number counts were not attempted. Sigurbjornsson et al. (1958) and Schertz and Murphy (1958) have demonstrated that aneuploids frequently occur in the octaploid B. inermis L.

Bromegrass accessions were grouped into four ploidy levels based on their DNA content (Table 1). The average DNA content $(2 \mathrm{C})$ for diploids $(2 n=14)$ and tetraploids $(2 n=28)$ were 6.14 and $11.74 \mathrm{pg}$, respectively, while the octaploids $(2 n=56)$ and the decaploids $(2 n=$ 70) had 22.31 and $26.53 \mathrm{pg} 2 \mathrm{C}^{-1}$, respectively. Accessions for which the standard deviation (SD) for the 10 analyzed plants was greater than $1 \mathrm{pg}$, had plants that differed in ploidy as determined by DNA content or had plants with DNA contents which were intermediate to the mean DNA contents for specific ploidy levels of that species. The plants with DNA contents intermediate between two ploidy levels were classified as potential aneuploids. Therefore, accessions with SD values greater than 1 were treated as mixtures; i.e., they contained plants differing in ploidy or contained some aneuploid plants.

Most B. inermis (94.3\%) and B. inermis ssp. pumpellianus $(77.7 \%)$ accessions had a DNA content that indicated they were octaploids while the majority of the B. riparius $(93.1 \%)$ and $B$. biebersteinii $(87.5 \%)$ had a DNA content that indicated they were decaploids (Tables 1 and 2). Hexaploid chromosome numbers $(2 n=$ 42) have been reported for B. inermis (Stahlin, 1929; Knobloch, 1943; Darlington and Janaki-Ammai, 1945). However, in this study, the DNA content measurement of more than $255 \mathrm{~B}$. inermis accessions, no plants with theoretical hexaploid DNA content were identified. This indicates that, at least in the current germplasm collection, hexaploids occur at a low frequency, if at all.

The average DNA content of the octaploid species were $22.15 \mathrm{pg}$ for B. riparius, $22.62 \mathrm{pg}$ for B. biebersteini,
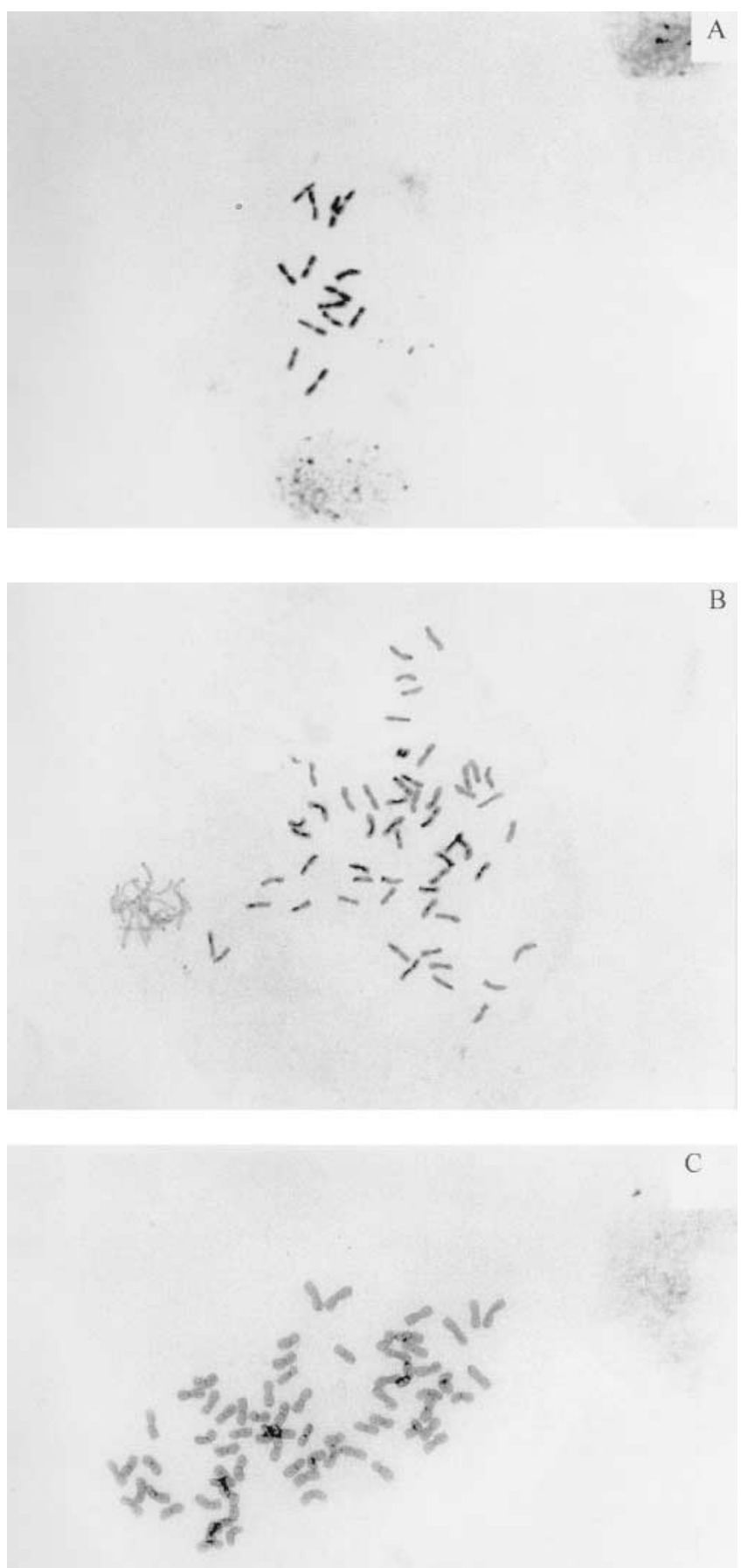

Fig. 4. Bromus riparius chromosomes from root-tip preparations. (A) Diploids (2n = 14; PI 440215); (B) Octaploid ( $n=56$; PI 315380); (C) Decaploid ( $2 n=70$; PI 536013).

$22.72 \mathrm{pg}$ for B. inermis ssp. pumpellianus, and 22.28 for $B$. inermis. The average DNA content of the four octaploid bromegrass species supports previous research which suggests that these octaploid species have a similar genomic structure and have very close genomic relationships (Pilay and Hilu, 1990; Vogel et al., 1996). Average DNA content of the decaploids was $26.07 \mathrm{pg}$ for B. biebersteini, $26.50 \mathrm{pg}$ for B. inermis ssp. pumpellia$n u s$, and $26.64 \mathrm{pg}$ for $B$. riparius. These results agree 
Table 2. Country of origin of bromegrass accessions, number of accessions in each species, ploidy classes, and total number of accessions contributed by each country.

\begin{tabular}{|c|c|c|c|c|c|c|}
\hline \multirow[b]{2}{*}{ Country } & \multicolumn{5}{|c|}{ Ploidy level } & \multirow[b]{2}{*}{ Total } \\
\hline & $2 x$ & $4 x$ & $8 x$ & $10 x$ & $\operatorname{Mix} \dagger$ & \\
\hline & 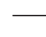 & & & $-\mathbf{n}$ & 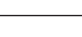 & 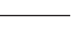 \\
\hline \multicolumn{7}{|l|}{ Bromus biebersteini } \\
\hline Unknown & & & & 3 & & 3 \\
\hline Former U.S.S.R. & & & 1 & & $\mathbf{1}$ & 2 \\
\hline Canada & & & & 3 & & 3 \\
\hline Turkey & & & & 1 & & 1 \\
\hline \multicolumn{7}{|c|}{ Bromus inermis spp. pumpellianus } \\
\hline Germany & & & 1 & & & 1 \\
\hline United States & & & 4 & 2 & & 6 \\
\hline Canada & & & 2 & & & 2 \\
\hline \multicolumn{7}{|l|}{ Bromus riparius } \\
\hline Former U.S.S.R. & 1 & & 2 & 27 & 5 & 35 \\
\hline Russian Federation & & & & 12 & & 12 \\
\hline Canada & & & & 2 & & 2 \\
\hline \multicolumn{7}{|c|}{ Bromus inermis ssp. inermis } \\
\hline Unknown & & & 8 & & & 8 \\
\hline United States & & & 26 & & $\mathbf{1}$ & 27 \\
\hline Turkey & & & 21 & & & 21 \\
\hline Sweden & & & 2 & & & 2 \\
\hline Spain & & & $\mathbf{1}$ & & & 1 \\
\hline Yugoslavia & & & 2 & & & 2 \\
\hline Former USSR & & 2 & $5 \overline{5}$ & & 2 & 59 \\
\hline Poland & & & 5 & & 1 & 6 \\
\hline Canada & & & 11 & & 1 & 12 \\
\hline Germany & & & 1 & & & 1 \\
\hline Romania & & & 5 & & & 5 \\
\hline Australia & & & 3 & & & 3 \\
\hline Norway & & & 1 & & & 1 \\
\hline Bulgaria & & & 1 & & & 1 \\
\hline Hungary & & & 2 & & & 2 \\
\hline Iran & & & 2 & & & 2 \\
\hline Japan & & & 14 & & 1 & 15 \\
\hline Russian Federation & & $\mathbf{1}$ & 57 & & 1 & 59 \\
\hline Kazakhstan & & 3 & 8 & & 1 & 12 \\
\hline China & & 8 & 5 & & & 13 \\
\hline Ukraine & & & 3 & & & 3 \\
\hline Total & 1 & 14 & 243 & 50 & 14 & 322 \\
\hline
\end{tabular}

$\dagger$ Accessions containing aneuploid plants or mixed ploidy level.

with previous reports which suggest that decaploid bromegrasses share some genomes with octaploid bromegrasses plus have an additional genome (Schults-Schaffer, 1960).

Bennett and Smith (1976) reported the DNA content of B. inermis as $23.6 \mathrm{pg} 2 \mathrm{C}^{-1}$ using Feulgen microdensitormetry with Secale cereale L. cv. Petkus Spring as the standard. The difference between their value and the value in this report is probably due to procedural differences.

The only designated genomes in the genus Bromus are A and B (Armstrong, 1991). On the basis of previous cytogenetic studies tetraploid $B$. inermis has the genomic composition of $\mathrm{AABB}$ while the octaploid form has AAAABBBB (Hill and Carnahan, 1957; Armstrong, 1973, 1979, 1982, 1991). The A and B genomes are believed to be closely related (Armstrong, 1979). The mean DNA content of the tetraploid and octaploid forms of $B$. inermis accessions support these cytogenetic findings because octaploids had almost twice the DNA content of the tetraploids. DNA content of the tetraploid, octaploid and decaploid accessions is approximately 2, 4 and 5 times larger, respectively, than the DNA content of plants of the diploid $(2 n=14) B$. riparius accession, PI 440215.

The expected DNA content in octaploids was twice that of tetraploids since the copy number of the same genomes in octaploids is twice that of tetraploids. However, the average DNA content of the octaploids was $1.2 \mathrm{pg}$ less than the expected amount (Table 1). These results indicate a slight tendency toward diminution of DNA content with increased ploidy. Compaction of DNA in polyploid nuclei can produce an underestimate of the DNA measurements (Verma and Rees, 1974; Kenton, 1984b) but it has also been observed in several cases where polyploids have smaller chromosomes and lower DNA content than expected (Yamaguchi and Tsunoda, 1969; Martinez and Ginzo, 1985; Poggio and Hunziker, 1986). Vogel et al. (1999) used flow cytometry to determine the base DNA content of the genomes of the perennial Triticeae and they concluded that gain or loss of nuclear DNA content occurred during the evolution of the perennial Triticeae and was probably a part of speciation. The variation in DNA content among bromegrass accessions within ploidy levels and the lower than expected DNA content of the higher ploidy plants is probably due to the gain or loss of DNA content during the evolution of these species and cytotypes.

Only one diploid accession (PI 440215), a B. riparius accession, was found among all the accessions surveyed. It was collected in Kazakhstan (Chimkent). Additional diploid accessions of this and related species would be extremely useful in determining the origin and genomic composition of the polyploid bromegrasses and also for genetic studies which are simpler to conduct at the diploid level than the polyploid level. Only 14 tetraploid accessions were found among accessions of $B$. inermis, two of which were collected in the former USSR. The remainder of the tetraploid accessions were mainly from China and Kazakhstan. Smooth bromegrass and meadow bromegrass are of Eurasian origin and the geographic regions from which diploid and tetraploid bromegrasses were collected is in the eastern range of the bromegrasses. Thus, additional collections of diploid and tetraploid species of $B$. inermis and related species are needed from other areas of Eurasia which are currently poorly represented in the collection.

Bromus inermis accessions in USDA NPGS were collected mainly from the former USSR and the USA. Accessions from the USA and Canada are cultivars and germplasms developed from introductions. Therefore, the USDA bromegrass collection does not represent all of the geographic regions where the smooth and meadow bromegrass occurs naturally. Additional collections are needed from Europe, the Middle East, and China to increase the diversity of bromegrasses in the USDA collection.

The percentage of accessions of the other three related species (B. biebersteinii, $B$. inermis ssp. pumpellia$n u s$, and $B$. riparius) within the bromegrass collection is very low and represent only a few geographic regions. Therefore, USDA bromegrass germplasm could be enhanced by collections from western and central Europe, the Middle East, and China to provide breeders with a larger diversity of germplasm for use in breeding programs.

The chromosome numbers of the accessions evalu- 
ated in this are now available on the USDA's National Plant Germplasm Systems GRIN database (http://www. ars-grin.gov/npgs/).

\section{REFERENCES}

Armstrong, K.C. 1973. Chromosome pairing in hexaploid hybrids from B. erectus $(2 n=28) \times$ Bromus inermis $(2 n=56)$. Can. J. Genet. Cytol. 15:427-436.

Armstrong, K.C. 1979. A and B genome homologies in tetraploid and octaploid cytotypes of Bromus inermis. Can. J. Genet. Cytol. 21:65-71.

Armstrong, K.C. 1982. Hybrids between the tetraploids of B. inermis and B. pumpellianus. Can. J. Bot. 60:476-482.

Armstrong, K.C. 1987. Chromosome numbers of perennial Bromus species collected in the USSR. Can. J. Plant Sci. 67:267-269.

Armstrong, K.C. 1991. Chromosome evolution in Bromus. p. 363-317. In T. Tsuchiya, and T.K. Gupta (ed.) Chromosome Engineering in Plants: Genetics, Breeding, Evolution. Part B. Elsevier, Amsterdam, the Netherlands.

Arumuganathan, K., and E.D. Earle. 1991a. Nuclear DNA content of some important plant species. Plant Mol. Biol. Rep. 9:208-219.

Arumuganathan, K., and E.D. Earle. 1991b. Estimation of nuclear DNA content of plants by flow cytometry. Plant Mol. Biol. Rep. 9:221-231

Arumuganathan, K., S.P. Tallury, M.L. Fraser, A.H. Bruneau, and R. Qu. 1999. Nuclear DNA content of thirteen turfgrass species by flow cytometry. Crop Sci. 39:1202-1207.

Barnett, F.L. 1955. A karyological survey of several Bromus species. Agron. J. 47:88-91.

Bennett, M.D., P. Bhandol, and I.J. Leitch. 2000. Nuclear DNA amounts in angiosperms and their modern uses-807 new estimates. Ann. Bot. (London) 86:859-909.

Bennett, M.D., and J.B. Smith. 1976. Nuclear DNA amounts in angiosperms. Phil. Trans. R. Soc. Lond. B. 274:227-276.

Brummer, E.C., P.M. Cazcarro, and D. Luth. 1999. Ploidy determination of alfalfa gerplasm accessions using flow cytometry. Crop Sci. 39:1202-1207.

Carnahan, H.L., and H. Hill. 1960. The nature of polyploidy in smooth bromegrass, B. inermis Leyss. J. Hered. 51:43-44.

Darlington, C.D., and E.K. Janaki-Ammai. 1945. Chromosome atlas of cultivated plants. Allen and Unwin, London, England.

Elliott, F.C., and E.P. Wilsie. 1948. A fertile polyhaploid in B. inermis. J. Hered. 39:377-380.

Gould, F.W., and R.B. Shaw. 1983. Grass systematics. 2nd ed. Texas A\&M Univ. Press, College Station, TX

Heslop-Harrison, J.S. 1995. Flow cytometry and genome analysis. Probe 5:14-17.

Hill, H.D., and W.M. Myers. 1948. Chromosome number in B. inermis Leyss. Agron. J. 40:467-472.
Hill, H.D., and H.L. Carnahan. 1957. Caryology of natural 4x, $6 x$, and $8 x$ progenies of a tetraploid $(4 x)$ clone of $B$. inermis Leyss. Agron. J. 49:449-452.

Hultquist, S.J., K.P. Vogel, D.J. Lee, K. Arumuganathan and S. Kaeppler. 1997. DNA content and chloroplast DNA polymorphisms among accessions of switchgrass from remnant Midwestern prairies. Crop Sci. 37:595-98.

Kenton, A. 1984. Use of pollen tetrads for routine DNA densitometry. J. Hered. 53:667-675.

Knobloch, I.W. 1943. Morphological variation and cytology of $B$. inermis. Bull. Torrey Bot. Club 70:467-472

Knowles, R.P., V.S. Baron, and D.H. McCartney. 1993. Meadow bromegrass. Agric. Can. Publ. 1889/E. Agric. Can., Ottawa, Canada

Lu, K., S.M. Kaepler, K.P. Vogel, K. Arumuganathan, and D.J. Lee. 1998. Nuclear DNA content and chromosome numbers in switchgrass. Great Plains Res. 8:269-80.

Martinez, A., and H.D. Ginzo. 1985. DNA content in Tradescantia. Can. J. Genet. Cytol. 27:766-775.

Pillay, M., and K.W. Hilu. 1990. Chloroplast DNA variation in diploid and polyploid species of Bromus (Poaceae) subgenera Festucaria and Ceratachloa. Theor. Appl. Genet. 80:326-332.

Poggio, L., and J.H. Hunziker. 1986. Nuclear DNA content variation in Bulnesia. J. Hered. 77:43-48.

Rayburn A.L., and J.A. Auger, E.A. Benzinger, and A.G. Hepburn. 1989. Detection of intraspecific DNA content variation in Zea mays L. by flow cytometry. J. Exp. Bot. 40:1179-1183.

Schertz, K.F., and R.P. Murphy. 1958. Fertility in relation to chromosome constitution and behavior in Bromus inermis Leyss. Agron. J. 50:372-376.

Schulz-Schaeffer, J. 1960. Cytological investigations in the genus Bromus: III. The cytotaxonomic significance of the satellite chromosomes. J. Hered. 51:269-277.

Sigurbjornsson, B., A. Mochizuki, and J.D. Truscott. 1958. Studies in the cytology of bromegrass, B. inermis Leyss. Can. J. Plant Sci. 38 111-117.

Stahlin, A. 1929. Morphologische und zytologische Untersuchungen an Gramineen. Pflanzenbau. 1:330-398.

Tsvelev, N.N. 1984. Grasses of the Soviet Union. I. (Russian Transl. Ser.) A. A. Balkema, Rotterdam, the Netherlands.

Verma, S.C., and H. Rees. 1974. Nuclear DNA and the evolution of allotetraploid Brassicace. Heredity 33:61-68.

Vogel, K.P., and J.F. Pedersen. 1993. Breeding systems for crosspollinated perennial grasses. Plant Breed. Rev. 11:251-274.

Vogel, K.P., K.J. Moore, and L.W. Moser. 1996. Bromegrasses. p. 535-567. In L.E. Moser et al. (ed.) Cool-season forage grasses. Agron. Monog. 34. ASA, CSSA, SSSA, Madison, WI.

Vogel, K.P., K. Arumuganathan, and K.B. Jensen. 1999. Nuclear DNA content of perennial grasses of the Triticeae. Crop Sci. 39: 661-667.

Yamaguchi, Y., and S. Tsunoda. 1969. Nuclear volume, nuclear DNA content and radiosensitivity in Brassica and allied genera. Jap. J. Breed. 19:350-356. 